Iraqi J. Vet. Med. 34 ( 2 ): 103 - 109; ( 2010 ).

\title{
Effect of the median lethal dose of the ethanolic extract of (Nerium Oleander) leaves on the histopathology features of the vital organs in mice
}

\author{
Ali Hussien Saliem \\ Dept. Physiology and Pharmacology, College of Veterinary Medicine, University of Baghdad.
}

Accepted - December - 2010

\section{Summary}

Nerium oleander leaves ethanolic extract at median lethal dose of $520 \mathrm{mg} / \mathrm{kg}$ body weight were administered orally to six male mice .Clinical signs of toxicosis in mice began to appear about $1 \mathrm{hr}$ after receiving the oleander extract which included abdominal pain, frequent urination, diarrhea, depression, weakness and convulsive movement and death at the end stage.Four mice died within 4 to $24 \mathrm{hrs}$ and two survived. Haemorrhage spots of varying degrees were observed in internal organs at necropsy.Histopathology revealed extensive tubular necrosis in kidneys with haemosiderin pigment in the cytoplasm of convoluted tubular cells, different degrees of coagulative necrosis in cardiac muscle cells associated with haemorrhage and infiltration of mononuclear inflammatory cells. Scattered necrosis of hepatocytes,congestion and oedema in lungs with severe congestion in the brain also observed histologically.

Key words: Narium oleander, ethanolic extract, mice.

Corresponding address:Bakir20062006@yahoo.com

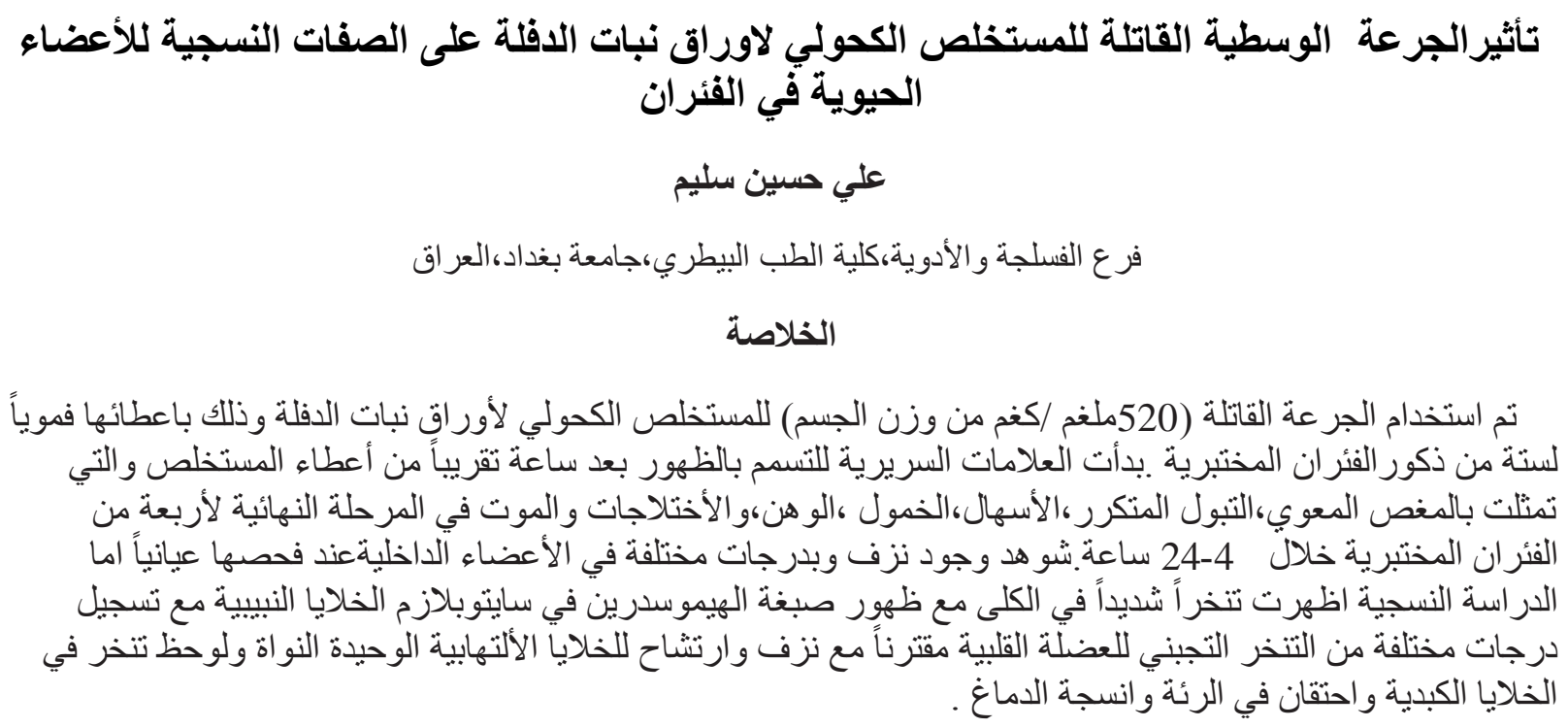


Iraqi J. Vet. Med. 34 ( 2 ): 103 - 109; ( 2010 ).

\section{Introduction}

Iraq is an agricultural country and the study of obnoxious plants which constitute a risk to man or livestock is therefore important since study of this type of vegetation will help to bring together up-date list of poisonous plant growing in Iraq(1).Nerium oleander: is an evergreen shrub or small tree in the dogbane family Apocynaceae.It is the only species currently classified in the genus Nerium.Other names include Adelfa, Alheli Extranjero, Baladre, Espirradeira, Flor De Sao Jose, Laurel De jardin, Laurel Rosa, Laurier Rose, Flourier Rose, Olean, Aiwa, Rosa Francesca, Rosa Laurel, and Rose-bay (2). Oleander exhibits digitalis - like effect, may cause glycoside poisoning with hyperkalemia (3). Ingestion can cause both gastrointestinal and cardiac effects. The lethal dose was capable on progressive changes in myocardial electrical activity ending up in cardiac arrest. The electrical abnormalities could be brought about by the expected $\mathrm{Na}^{+}-\mathrm{K}^{+}$-ATPase inhibition by the glycosides (cardinolides) content of the lethal dose. All parts of the plant are toxic. Toxicity do not deteriorate through cultivation (1). This extremely toxic plant can poison livestock and humans over all of the year (4). Boiling or drying the plant does not inactive the toxin and poison have been reported from the smoke of burning oleander or use of the branches as skewers for food (5, 6 and 7).The most significant of these toxins are oleandrin and neriine and oleanders contain a toxin called cardinolides, which are cardiac glycoside (8). Oleander bark contains rosagenin which known for its strychnine like effects (9 and 10). All animals can suffer a reaction or death from this plant (11). Parts of inactivate plant can be ingested accidentally or in suicide attempts (12). The plant exudes a thick white sap when a twig or branch is broken or cut $(13,14$ and 9). Oleander sap can cause skin irritation, sever eye inflammation and irritation, allergy reactions characterized by dermatitis (8).this experiment designed to study the effect of the median lethal dose on the histopathology features of the vital organ in the mice.

\section{Materials and methods}

Twelve male mice (Albino, Sprigue Dawlly) were obtained from University of Baghdad, Cancer Research Center. Male mice 10 weeks old weighing 20-35 g were maintained under uniform environmental conditions. They were housed under controlled temperature 25 ${ }^{\circ} \mathrm{C}$ and exposed to light 12 hours per day before and during study. The mice were placed in shoebox cages (Opaque and plastic) and supplied with feed (Pellets form, commercial type) ad libitum. The animals were adapted for 2 weeks. The animals were divided into two equal groups, (6 male mice in each group) which were treated as follows: first group treated orally with LD50 dose $(520 \mathrm{mg} / \mathrm{kg} \mathrm{B.w})$ of alcoholic extract of $N$.oleander leaves as aqueous solution (15) ,second group was give normal saline and saved as control. Collection of the plant and processing: Fresh leaves of local planted pink oleander were collected from North of Baghdad, in January then identified by the Ministry of Agriculture-State Board for Seed-Testing and Certification (SBSTC), Abu-Ghraib, which were classified as Nerium oleander. Then the leaves dried at room temperature in open air and ground by an electrical grinder, the ratio of dried part $(1.5 \mathrm{Kg})$ weight to original weight $(4 \mathrm{Kg})$ was calculated, and then kept in glass containers which were closed to be used in the other parts of this experiment. Alcoholic extract: Alcoholic extract of plant leaves content was carried by using $70 \%$ ethyl alcohol. One hundred grams of dried leaves was mixed with $500 \mathrm{ml}$ of alcohol in every extract process by using magnetic stirrer at $35-40{ }^{\circ} \mathrm{C}$ for 24 hours according to method of (16 and 17), the extract was filtered and the process was repeated three times .the filtrate was evaporated by rotary evaporator using negative pressure at $39^{\circ} \mathrm{C}$ degree temperature. The resulted extract was weighed and kept at $-20^{\circ} \mathrm{C}$. Preparation of the stock solution, concentrations and doses of N.oleander Alcoholic extract:The dilutions of the N.oleander extract were prepared according to the method of (18) by using the distilled water as diluant solution by weighing $(1000 \mathrm{mg})$ of 
Iraqi J. Vet. Med. 34 ( 2 ): 103 - 109; ( 2010 ).

the extract and then dissolved by distilled water to complete the volume to (10) $\mathrm{ml}$, the stock concentrations were recorded as (weight/volume) $(100 \mathrm{mg} / \mathrm{ml})$ while the final concentration of $26 \mathrm{mg} / \mathrm{ml}$ and dose volume of $0.2 \mathrm{ml} / 10 \mathrm{gm} \mathrm{B}$.W for dosing mice with LD50 dose of $520 \mathrm{mg} / \mathrm{kg}$ was prepared as in table (1).

Table (1): Standard dose and dilution of N.oleander alcoholic extract.*0.2 ml/10 gram of mouse.

\begin{tabular}{|l|l|l|}
\hline $\begin{array}{l}\text { Alcoholic extract } \\
\text { dose }(\mathbf{m g} / \mathrm{kg})\end{array}$ & Solution concentration $\mathrm{mg} / \mathrm{ml}^{*}$ & Stock of $(100 \mathrm{mg} / \mathrm{ml})$ \\
\hline $\mathbf{5 2 0}$ & 26.0 & $2.60 \mathrm{ml}$ q.s $10 \mathrm{ml}$ \\
\hline
\end{tabular}

Necropsy of animals was performed immediately after death and gross pathology of organs were recorded. To examine microscopic lesions, tissue samples of brain, liver,heart, kidneys, lungs were collected, fixed in $10 \%$ neutral buffered formalin, and processed for routine histology. Tissue sections were stained with haematoxylin and eosin. Dosing of mice: Mice were treated with the plant extract by using modified stomach tube consist of insulin syringe and curved blind canula needle (gauge 17).

\section{Results}

Clinical findings:Abdominal pain, manifested by restlessness, pawing the ground, looking at the flank, frequent lying down and getting up, and humped posture about $1 \mathrm{hr}$ after oleander administration.diarrhoea, salivation with foam in the mouth, depression, weakness, incoordination of movements, tachypnea , convulsion and death of four mice of extract group was reported at the end stage. Pathology: At gross, the observed lesions were congestion of visceral organs including liver, kidney, lungs, intestines and hemorrhages in the left ventricular endocardium were observed Histopathological examination showed the following:

1-In the animals which were died suddenly there was odema, congestion and endothelial proliferation in the lung (figure1), while there was coagulative necrosis and lymphatic aggregation in the liver (figure2).

2-In the animals which died after $24 \mathrm{hrs}$ there was congestion, acute cellular degeneration (swelling) of renal tubules and boman space dilatation in the kidney(figure 3 ), the lungs were suffering from congestion, hyperplasia of pithelial lining of bronchiol, odema ,congestion, thrombosis and thickening of alveolar wall due to lymphatic infiltration also around bronchiol(figure 4 ), also there was lymphatic infilteration, vacculation,coagulative necrosis and few hemosidrin pigment in the liver (figure 6 ), while there was only thrombosis in the heart(figure5).

3-In the animals which sacrificed after $72 \mathrm{hrs}$ there is congestion in the lung, perivascular odema in the brain(figure7 ) and congestion of the capillaries in the kidney. 


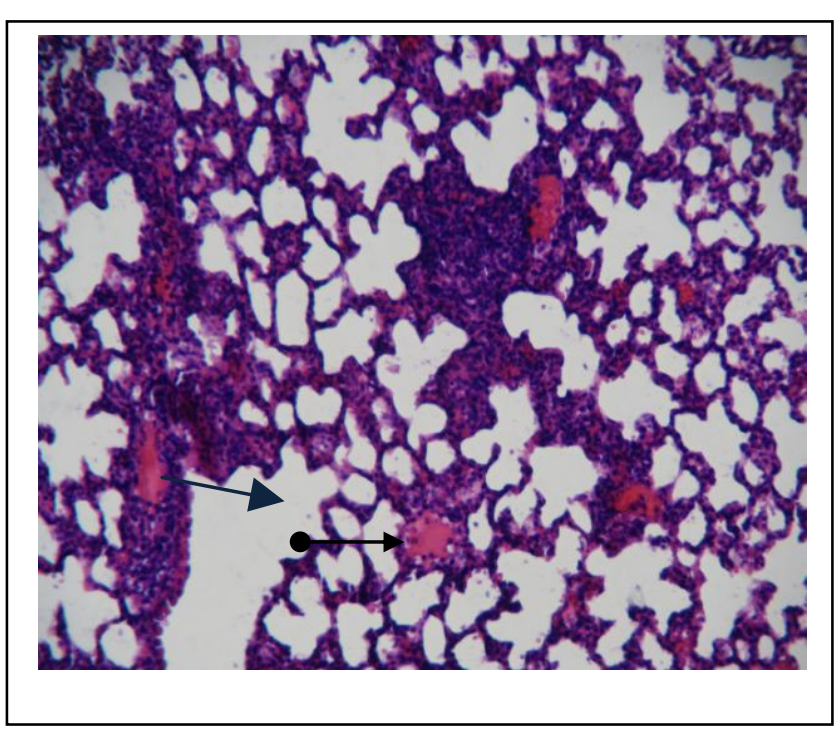

Figure (1): There is odema $(\longrightarrow$ ), congestion( $\bullet$ ) in the lung. $(\mathrm{H} \& \mathrm{E} \times 10)$.

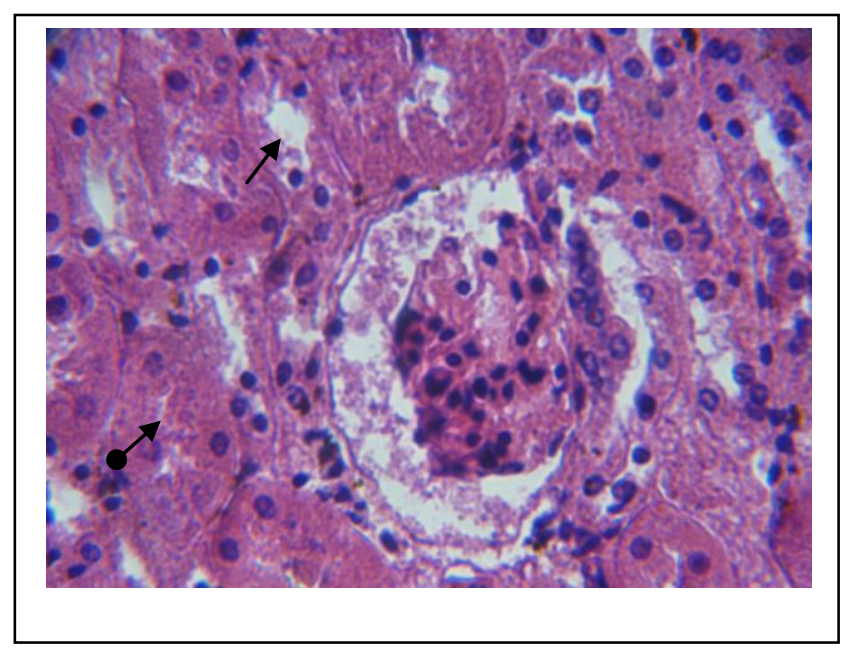

Figure(3):There,acutecellular degeneration (swelling) of renal tubules $(\bullet)$ and boman space dilatation( $\longrightarrow$ ) in the kidney. (H\&E $\times 40$ ).

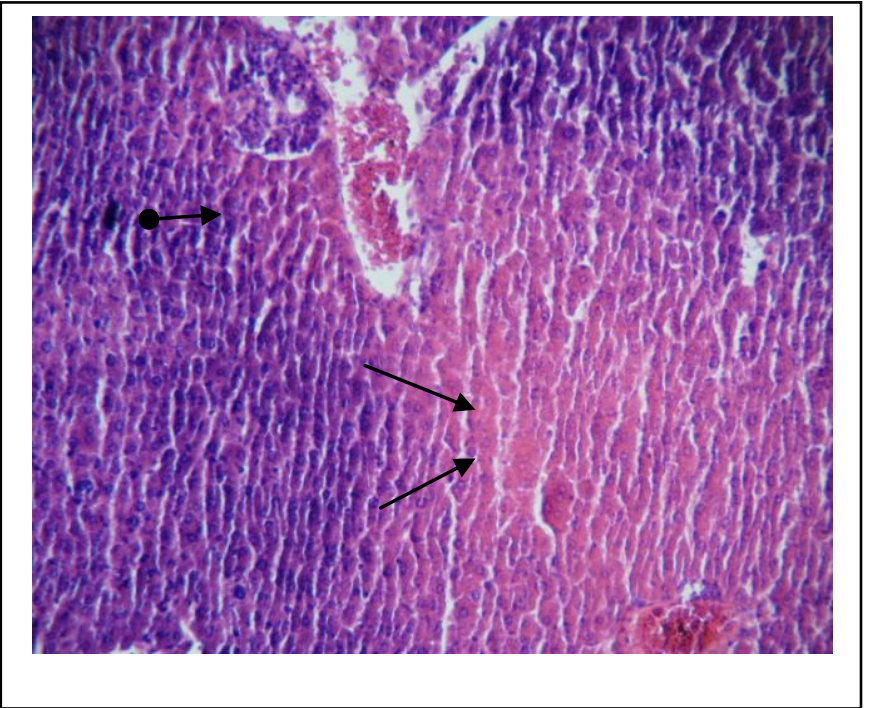

figure(2): There is coagulative necrosis( $\rightarrow$ ) and lymphatic aggregation in the liver $(\bullet)$. (H\&E $\times 10)$.

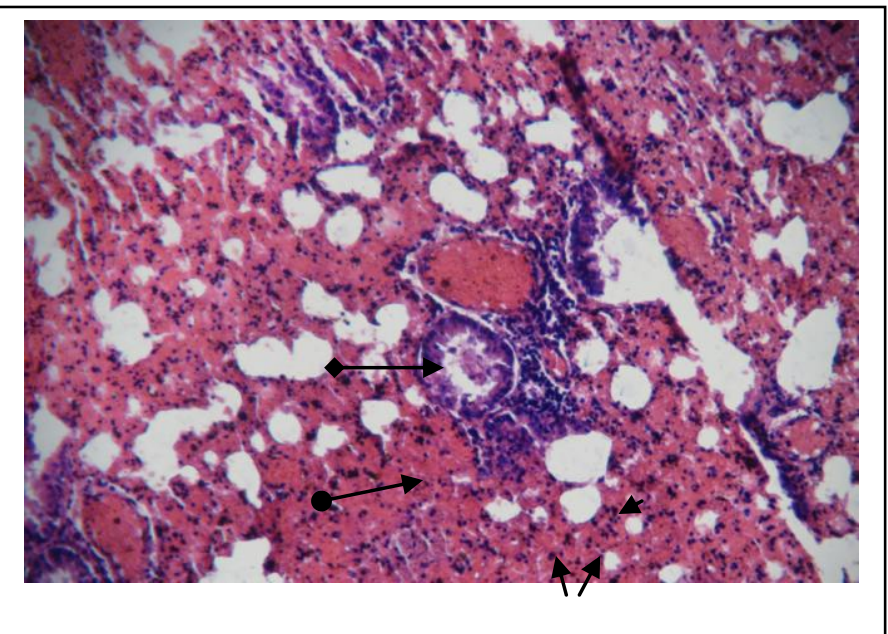

Figure(4):The lung was suffering from congestion,hyperplasia of epithelial lining of bronchiol( $\bullet$ ),odema,thrombosis( $\longmapsto$ ) and thickening of alveolar wall due to lymphatic infiltration $(\rightarrow$ )also around bronchiole (H\&E $\times 10)$. 
Iraqi J. Vet. Med. 34 ( 2 ): 103 - 109; ( 2010 ).

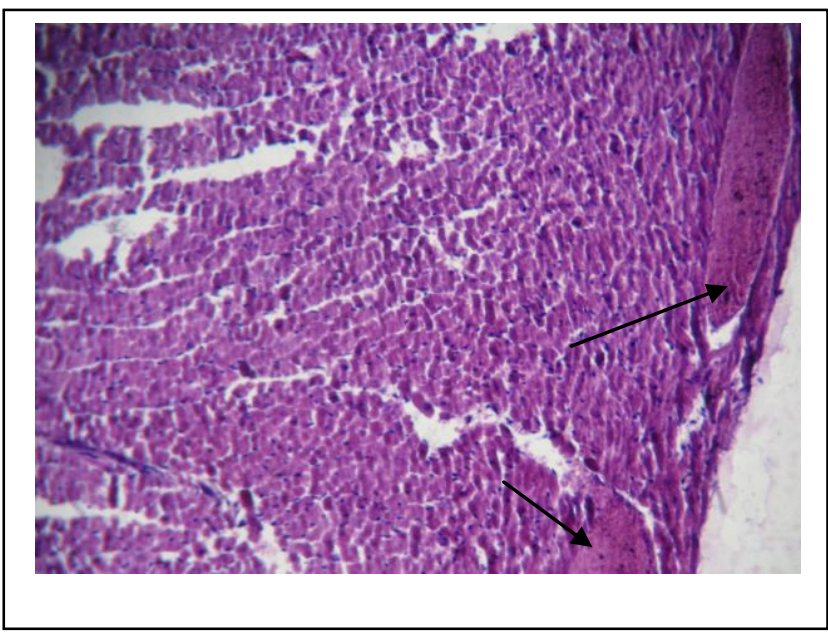

Figure(5):There is only thrombosis ( $\longrightarrow$ ) in the heart. (H\&E ×10).

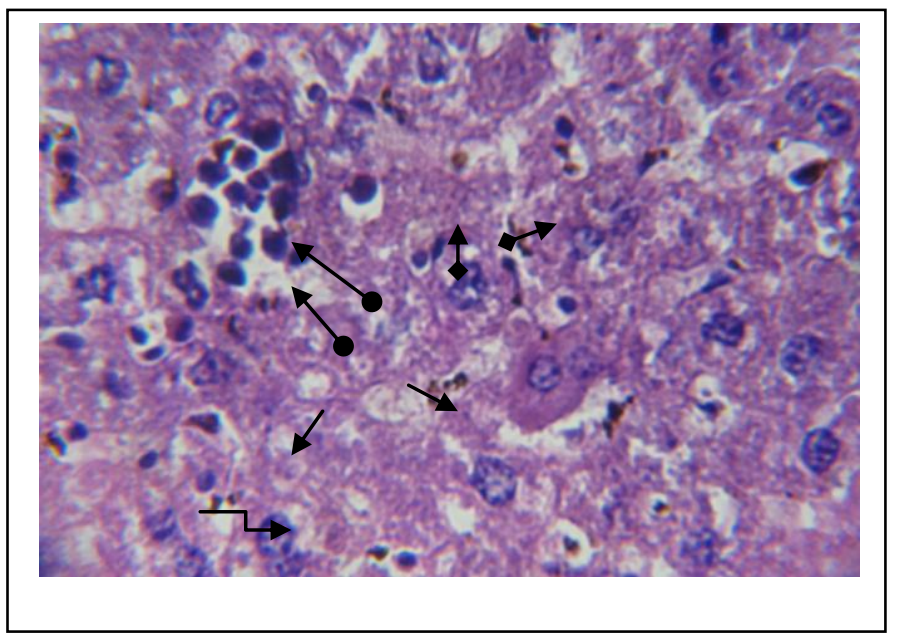

Figure(6):There is lymphatic infilteration( $\longrightarrow$ ),vacculation $(\rightarrow$ ),coagulative necrosis $(\neg)$ ) and few emosidrin pigment $(\longmapsto)$ in the liver. (H\&E ×40)

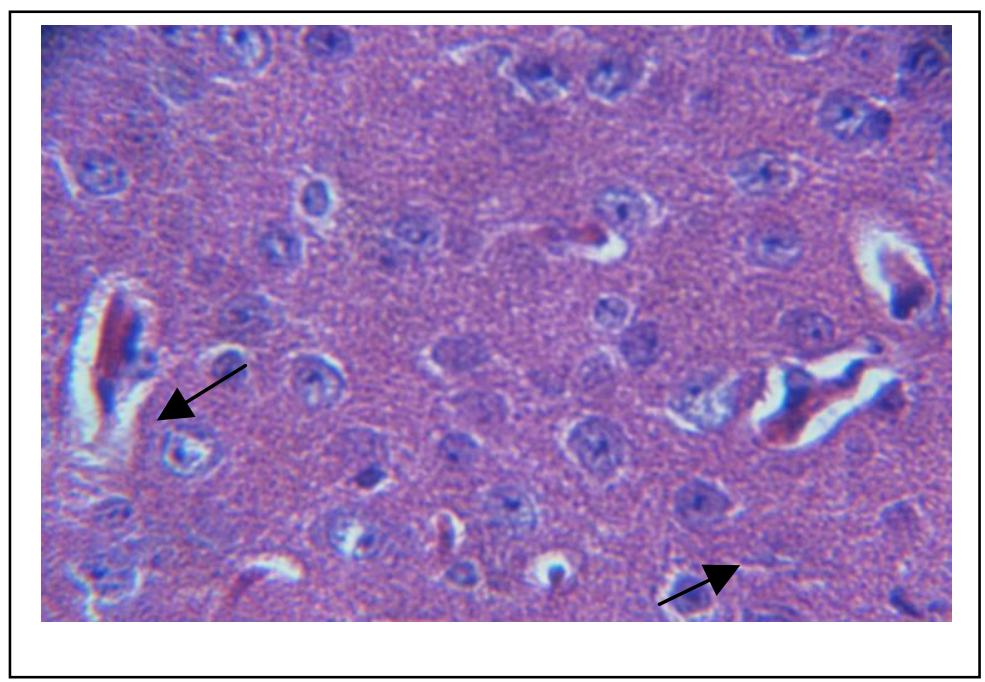

Figure(7): Perivascular odema in the brain $(\rightarrow)$. (H\&E $\times 40)$. 
Iraqi J. Vet. Med. 34 ( 2 ): 103 - 109; ( 2010 ).

\section{Discussion}

Clinical and pathological findings of oleander intoxication in mice reported in this study are generally consisted with those reported in other animals (19 and 20). The main clinical signs observed were related to digitalis like toxicosis in human and small animals and are related to effect on central nervous system (7,9 and 21 ). Effects of oleander glycosides on the kidneys of mice manifested clinically by frequent urination and tubular necrosis in pathology. Diuretic effect of glycosides is also known and induced event by subtrapeutic dose. The diuretic effect is interpreted as evidence that $\mathrm{Na}+\mathrm{K}+$ _ ATPase is involved in urine concentration mechanism and by inhibiting this enzyme, cardiac glycosides could evoke a direct diuretic effect on the kidneys. On the other hand, in congestive heart failure patients,circulatory effect of cardiac glycosides increases the renal blood flow and glomerular infiltration (21). The cause of renal tubular necrosis in oleander toxicosis is unidetified. Tubular cells of kidneys are probably exposed to much amounts of oleander toxins due to their excretion from this organ. Intracellular $\mathrm{Ca} 2+$ elevation following inhibition of $\mathrm{Na}+\mathrm{K}+-\mathrm{ATPase}$ may also be involved in tubular cell degeneration and necrosis. Uptake of oleandrin in brain after dosing with oleander extract has been reported in mice. It has also been shown that the component within oleander extract enhances transport of oleandrin across the blood brain barrier (22). The oleander toxins may cross the blood brain barrier; however, the brain lesions are caused secondary to vascular endothelial damage and acute heart failure, and direct effect of the toxins on the cells. Pulmonary lesions may also be produced by vascular endothelial damage and acute left heart failure. Among different species of domestic animals, cattle are more prone to eat oleander leaves. Housing of cattle indoors and non-selective feeding predispose them to intoxication (23and 24). Based on the findings of the present study, it is concluded that the oleander have risk effect and the laboratory animals of rodent species because of very low susceptibility are not full useful for experimental studies on cardiac glycosides (23and 25). Therefore, sheep and goats are convenient animals for this object and using them in the experimental studies of poisoning with oleander or other sources of cardiac glycosides will help to elucidate unknown aspects of the toxicosis with these compounds in the future.

\section{References}

1-AL-Rawi Ali (1966). Poisonous plants of Iraq. Nerium oleander lin.,p.83-84;Technical Bulletin No.145;printed at the government press,Baghdad.

2-Kunkle DB (1983). Poisonous plants. In: Haddad LM and Winchester JF eds. Clinical management of poisoning and drug overdose. Philadelphia, Saunders. P.317.

3-Kunkle DB and Spoerke DG (1984). Evaluating exposures to plants. Emerg. Med Clin North Am. 2:133-144.

4-John W Everest D Thomas A Powe J John D and Freeman L (2007). Poisonous plants of the Southeastern United States. Alburn University .p.1-3.

5-Riffle RL (1998). The tropical look. An encyclopedia of dramatic landscape plants .Timber press.p.8.

6-Haynes BE Bessen HA and Wightman WD (1985). Oleander tea: herbal drought of death.Ann Emerg Med. 14: 350-353.

7-Shaw DE and Pearn J (1979). Oleander poisoning. Med J Aust. 2: 267-269. 
Iraqi J. Vet. Med. 34 ( 2 ): 103 - 109; ( 2010 ).

8-Goetz Rebecca J (1998). Oleander.Indina plants poisons to livestock andpets. Cooperative Extension Service, Purdue University, Retrieved on 2005-10-23.

9-Pearn J (1987). Oleander poisoning. In:Covacevich, J Davie P and Pearn J (Eds.),Toxic plants and animals: a guide for Australia. (1st. Edn.), QLD Museum,Brisbane. PP: 37-49.

10-Schvartsman S (1979). Plantas venenosas.first edition Sarvier Sao Paulo.p. 225.

11-Hensley D (1997).Ornamentals and flowers.Oleander.(CATAHR)college of tropical agriculture and human resowrses.University of Hawaii al Mono.pp.1-6.

12-Pronczuk J and Laborde A (1988). Plantas silvesters Y de cultiro : riesgo de intoxication para el hombre. Montevideo, Universidad de la Republica.pp.5 and pp.25.

13-Font-Quer P (1979). Plantas medicinales. Barcelona, Ed. Labor, SA.p.301.

14-Lampe KF and McCann MA (1985). AMA Handbook of Poisonous and Injurious Plants. Chicago, Illinois, American Medical Association.pp.240

15-Salih RA(2008). Study of Acute Toxicity of Different extracts of Oleander (Nerium Oleander) Leaves in Mice.M.Sc.thesis.Vet. Medicine.Baghdad univ.pp.36

16-Harborne JB (1973). Phytochemical methods. Halste Press. John Wiley and Sone New York. Pp: 278.

17-Harborne JB (1984). Phytochemical methods. A guide to modern techniques of plat analysis. Chaman and Hall, $2^{\text {nd }}$ ed. New York,pp: 288.

18-Ammash HS AL-Jahir H Hameed Z Mohammed S and Mamza H (1993). Antimicrobial activity of tea extract against gram positive and gram negative bacteria. Iraqi J Microbiol. 5(1):1-13.

19-Oryan A Maham M Rezakhanu A and Maleki M (1996). Morphological studies on experimental oleander poisoning in cattle. J Vet Med Series A. 43: 625-634.

20-Aslani MR Movassaghi AR Mohri M Abbasian A and Zarehpour M (2004).Clinical and pathological aspects of experimental oleander (Nerium oleander)toxicosis in sheep. Vet Res Commun. 28:609616.

21-Adams HR (1995). Digitalis and vasodilator drugs. In: Adams, HR (Ed.), Veterinary pharmacology and therapeutics. (7th. Edn.),Ames, Iowa State University Press. PP: 451-482.

22-Ni D MaddenTL Johansen M Felix E Ho DH and Newman RA (2002). Murine pharmacokinetics and metabolism of oleandrin, a cytotoxic component of Nerium oleander. J Exp Ther Oncol. 2: 278-285.

23-Joubert JPJ (1989). Cardiac glycosides. In:Cheeke, PR (Ed.), Toxicant of plant origin.Vol II, Glycosides. (1st. Edn.), Florida, CRC Press. PP: 61-69.

24-Galey FD Holstege DM Pulmee KH Tor E Johnson B Anderson ML Blanchard PC and Brown F (1996). Diagnosis of oleander poisoning in livestock. J Ve Diagn Invest. 8: 358-364.

25-Langford SD and Boor PJ (1996). Oleander toxicity: an examination of human and animal toxic exposure. Toxicology. 109: 1-13. 